\title{
Proliferasi In Vitro Plb Anggrek Dendrobium lasianthera Hasil Induksi Mutasi Genetik dengan Kolkisin Melalui Penambahan Benzyl Adenine
}

\author{
In Vitro Proliferation of Cholchicine-Induced Plb Mutant of Dendrobium lasianthera \\ by Benzyl Adenine Addition
}

\author{
Gilar Bawonoadi, Ni Made Armini Wiendi", dan Krisantini
}

\author{
Departemen Agronomi dan Hortikultura, Fakultas Pertanian, Institut Pertanian Bogor (Bogor Agricultural \\ University), Jl. Meranti, Kampus IPB Darmaga, Bogor 16680, Indonesia \\ Telp. \& Faks. 62-251-869353 e-mail agronipb@indo.net.id \\ *Penulis untuk korespondensi: nmarmini@gmail.com
}

Disetujui 17 Mei 2017/Published online 22 Mei 2017

\begin{abstract}
Dendrobium lasianthera is an orchid native species from Papua. Proliferation and propagation of plants through tissue culture is one of the methods to multiply rare species that are limited in number. Variance in characteristics of ornamental plants, either naturally-occurred or induced through mutation, is considered important in determining their economic values. The development of propagation protocols requires studies on suitable medium for plant propagation. This study is aimed at determining the effects of benzyl-adenine (BA) in the culture media on D. lasianthera proliferation. D. Plb (protocorm-like body) of Dendrobium lasianthera were previously treated with colchicine to induce mutation. The growth of 960 explants treated with 16 combinations of chemical mutation (including control) grown in MSO medium added with $1 \mathrm{mgL}^{-1}$ dan $2 \mathrm{mgL}^{-1}$ BA (6-Benzyl-adenine) was evaluated. Result showed the different colchicine treatments resulted in difference in growth of explants compared to control, particularly in the number of leaves, roots, plb and shoots. BA has no significant different effect to number of leaves, roots and plb formation, but increased number of shoots and their formation rate. Explants grown in $2 \mathrm{mgL}^{-1} B A$ media had more shoots than those in $1 \mathrm{mgL}^{-1}$. media. Explants cultured in $1 \mathrm{mgL}^{-1}$ BA media have shorter shoot formation period compared to $2 \mathrm{mgL}^{-1}$ media. Several mutation-induced explants had phenotypic differences compared with control, i.e. wavy leaf shapes.
\end{abstract}

Keywords : Dendrobium lasianthera, colchicine, BA (6-Benzyladenine), plb (protocorm-like body)

\begin{abstract}
ABSTRAK
Dendrobium lasianthera merupakan spesies anggrek yang endemik di Papua. Proliferasi atau perbanyakan tanaman melalui kultur jaringan merupakan salah satu alternatif dalam memperbanyak spesies tanaman dengan jumlah individu yang terbatas. Keragaman karakteristik pada tanaman hias, baik yang bersifat alami atau hasil dari induksi mutasi, dianggap penting dalam menentukan nilai ekonomisnya. Pengembangan protokol produksi membutuhkan penelitian terkait media yang sesuai untuk memperbanyak tanaman. Penelitian dilakukan dengan mengkulturkan eksplan anggrek Dendrobium lasianthera berupa plb (protocorm-like body) dari anggrek D. lasianthera yang telah diinduksi mutasi melalui perendaman dalam larutan mutagen kolkisin pada penelitian sebelumnya. Pengamatan dilakukan terhadap kemampuan pertumbuhan 960 eksplan dari 16 kombinasi perlakuan (termasuk kontrol) perendaman kolkisin ditumbuhkan pada media MSO yang ditambahkan sitokinin BA (6-Benzyladenine) sebanyak $1 \mathrm{mgL}^{-1}$ dan 2 $m g L^{-1}$. Hasil penelitian menunjukkan bahwa eksplan dengan kombinasi perlakuan perendaman yang berbeda memiliki kemampuan pertumbuhan yang berbeda secara nyata, dilihat dari jumlah daun, akar, plb dan tunas baru yang terbentuk selama periode pengamatan.Perbedaan dalam konsentrasi BA dalam media tidak menunjukkan respon yang berbeda nyata dalam jumlah daun dan akar baru yang terbentuk, namun nyata meningkatkan jumlah tunas baru yang terbentuk dan mempercepat pembentukan tunas. Eksplan yang ditumbuhkan pada media BA $1 \mathrm{mgL}^{-1}$ memiliki rata-rata waktu awal pembentukan tunas yang lebih singkat dibandingkan dengan media BA $2 \mathrm{mgL}^{-1}$. Beberapa planlet hasil induksi mutasi menunjukkan perbedaan fenotipe dari planlet kontrol berupa bentuk daun yang berbeda.
\end{abstract}

Kata kunci : Dendrobium lasianthera, kolkisin, BA (6-Benzyladenine), plb (protocorm-like body) 


\section{PENDAHULUAN}

Anggrek dari famili Orchidaceae merupakan tanaman hias yang banyak diminati di dunia. Jumlah anggota spesies ini berkisar sekitar 25000 spesies, dan merupakan famili tanaman bunga dengan jumlah spesies terbanyak (Cardoza 2008). Indonesia merupakan salah satu negara dengan keanekaragaman anggrek yang tinggi, dengan jumlah spesies sebanyak sekitar 2000 spesies (Irawati 2002). Nilai produksi anggrek di Indonesia pada tahun 2013 mencapai 20277672 tangkai, dengan total luas panen $1336677 \mathrm{~m}^{2}$ dan nilai ekspor total mencapai 4254195 US\$ (BPS 2014). Jumlah tanaman anggrek yang diperdagangkan di seluruh dunia mencapai 25 juta tanaman per tahun (Clemente 2009). Besarnya permintaan terhadap tanaman anggrek dan tingginya tingkat produksi menjadikan tanaman anggrek berpotensi menjadi komoditas pendukung perekonomian Indonesia.

Peningkatan permintaan terhadap tanaman anggrek mendorong dilakukannya pengembangan keragaman produk anggrek untuk meningkatkan keragaman genetik anggrek, terutama untuk mendapatkan bentuk dan warna bunga anggrek yang menarik dan berkualitas baik. Teknologi diperlukan untuk mewujudkan peningkatan keragaman genetik tersebut, salah satu metode yang dapat dilakukan untuk menciptakan keragaman adalah aplikasi kolkisin.

Induksi mutasi tanaman menggunakan kolkisin merupakan salah satu metode induksi mutasi yang paling banyak digunakan dalam pemuliaan tanaman (Harten 1998). Kolkisin (colchicine) merupakan mutagen berupa senyawa alkaloid yang dapat diekstrak dari tanaman Colchicum autumnale. Aplikasi kolkisin terhadap sel dapat menyebabkan penggandaan jumlah kromosom, perbedaan distribusi kromosom dan mutasi titik (Franzke dan Ross 1957). Kondisi sel yang mengalami penambahan jumlah set kromosom disebut poliploidi. Adanya perubahan jumlah atau susunan kromosom dapat mengakibatkan perubahan dalam proses ekspresi gen, sehingga fenotipe organisme berubah. Perubahan fenotipe yang terjadi mencakup perubahan sifat morfologis maupun fisiologis.

Beberapa faktor dapat mempengaruhi cara kerja kolkisin terhadap peningkatan keragaman genetik pada tanaman. Pengaruh kolkisin dapat bervariasi tergantung jenis tanaman, konsentrasi yang digunakan dan lama perendaman (Dooghe $e t$ al. 2010.). Tanaman yang telah mengalami induksi mutasi dan berhasil bertahan hidup perlu melalui berbagai macam pengujian sebelum dapat diperbanyak secara luas untuk kepentingan tertentu. Salah satu bentuk pengujian yang penting untuk dilakukan adalah pengujian kemampuan proliferasi planlet setelah mendapat perlakuan kolkisin. Penggunaan zat pengatur tumbuh (ZPT) dalam media kultur berperanan penting dalam proliferasi kultur in vitro.

Penelitian yang telah dilakukan oleh Sarathum et al. (2010) serta Yenchon dan Techato (2014) menunjukkan bahwa konsentrasi larutan kolkisin dan lama perendaman mempengaruhi persentase tanaman yang mengalami poliploidi pada tanaman Dendrobium. Plb (protocorm-like body) Dendrobium scabrilingue yang direndam dalam waktu yang lebih lama cenderung lebih mudah mengalami mutasi kromosom. Persentase poliploidi terbanyak diperoleh pada perendaman menggunakan kolkisin dengan konsentrasi $0.075 \%$ (Sarathum et al. 2010). Perbedaan dalam perlakuan kolkisin pada Dendrobium formosum mempengaruhi diferensiasi plb serta jumlah kromosom. Perlakuan kolkisin yang berbeda menghasilkan jumlah kromosom yang bervariasi berupa miksoploid hingga tetraploid (Yenchon dan Techato 2014). Penelitian induksi mutasi melalui perendaman dengan kolkisin telah dilakukan pada beberapa spesies anggrek Dendrobium dan hasil penelitian tersebut telah bermanfaat untuk memperbaiki fenotipe tanaman.

Benzyl Adenine (BA), atau 6Benzyladenine merupakan ZPT sintetik yang umum digunakan dalam perbanyakan tanaman in vitro. BA digolongkan kedalam sitokinin berdasarkan fungsinya dalam mengatur pertumbuhan dan perkembangan tanaman. Respon tanaman yang umum diperoleh dari aplikasi BA ialah peningkatan pembentukan tunas. BA sebagai sitokinin sintetik memiliki kelebihan berupa ketahanan metabolik yang lebih tinggi dibandingkan dengan sitokinin alamiah berkat struktur kimiawinya (Srivastava 2002). Hal ini membuat BA dapat memberikan pengaruh terhadap pertumbuhan dan perkembangan tanaman dalam jangka waktu yang relatif lebih lama. Aplikasi BA pada Dendrobium telah diketahui dapat menginduksi pembentukan tunas (Sakai 1998). BA seringkali dipadukan dengan ZPT lain seperti auksin untuk memperoleh tingkat pertumbuhan atau perkembangan organ yang diharapkan. Konsentrasi BA yang digunakan dalam studi proliferasi plantlet anggrek berkisar antara $0.45 \mathrm{mgL}^{-1}$ hingga $9.96 \mathrm{~mL}^{-1}$ (Sarathum et al. 2010). Hasil yang diperoleh dari pengujian ini akan bermanfaat untuk menentukan protokol perbanyakan tanaman-tanaman hasil induksi mutasi, sehingga diperoleh plantlet dengan jumlah banyak untuk proses seleksi fenotipe selanjutnya. 
Penelitian ini bertujuan untuk mempelajari kemampuan proliferasi anggrek Dendrobium lasianthera yang sebelumnya mendapat perlakuan induksi mutasi dengan kolkisin, dan ditumbuhkan pada media dasar Murashige dan Skoog dengan dua konsentrasi BA.

\section{METODE PENELITIAN}

Penelitian ini dilaksanakan di Laboratorium Kultur Jaringan Tanaman II, Departemen Agronomi dan Hortikultura, Fakultas Pertanian, Institut Pertanian Bogor. Penelitian dilakukan mulai bulan April 2015 hingga Juli 2015.

Bahan tanaman yang digunakan adalah $p l b$ dan tunas anggrek $D$. lasianthera yang telah diberi perlakuan induksi mutasi melalui perendaman dalam kolkisin pada penelitian sebelumnya oleh Nugroho (2015), yang ditumbuhkan pada media MS53 (media dasar MS $+0.5 \mathrm{mgL}^{-1} \mathrm{IAA}+1.5 \mathrm{mgL}^{-1} \mathrm{BA}+50 \mathrm{ml}$ air kelapa). Media kultur jaringan yang digunakan untuk kultur proliferasi eksplan hasil induksi mutasi adalah media dasar MS dengan $\mathrm{pH} 6.0$ yang ditambahkan dengan $0.5 \mathrm{mgL}^{-1} \mathrm{NAA}$ (1Naphtaleneacetic acid), $50 \mathrm{mlL}^{-1}$ air kelapa, 30 $\mathrm{gL}^{-1}$ sukrosa, $7 \mathrm{gL}^{-1}$ agar dan dua taraf konsentrasi BA $\left(1 \mathrm{mgL}^{-1}\right.$ dan $\left.2 \mathrm{mgL}^{-1}\right)$.

Peralatan yang digunakan mencakup autoklaf, scalpel, gunting, pisau, cawan petri, pinset, gelas ukur dan botol kultur. Laminar air flow cabinet digunakan sebagai tempat untuk mengkulturkan tanaman secara in vitro. Lampu LED $8 \mathrm{~W}$ dengan intensitas cahaya rata-rata $\pm 733 \mathrm{lux} / \mathrm{m}^{2}$ dengan lama penyinaran 16 jam per hari. Suhu ruang kultur diatur pada kisaran $20-23^{\circ} \mathrm{C}$.

Penelitian dilakukan menggunakan rancangan faktorial dua faktor yang disusun secara rancangan acak lengkap (RAL). Faktor pertama adalah mutasi dengan kolkisin yang terdiri atas 15 taraf ditambah dengan 1 kontrol, dan faktor kedua adalah konsentrasi BA yang digunakan dalam media kultur $\left(1 \mathrm{mg} \mathrm{L}^{-1}\right.$ dan $2 \mathrm{mg}$ $\left.\mathrm{L}^{-1}\right)$. Faktor perlakuan dengan kolkisin terdiri atas 16 taraf perlakuan kolkisin yang merupakan kombinasi dari konsentrasi kolkisin $(0 \%, 0.025 \%$, $0.05 \%$ dan $0.075 \%$ ) dan lama perendaman dengan kolkisin (1 jam, 24 jam 48 jam dan 72 jam). Kombinasi perlakuan kolkisin terdiri atas kontrol (C00), konsentrasi kolkisin 0\% dan lama perendaman 1 jam (C01), konsentrasi kolkisin $0 \%$ dan lama perendaman 24 jam (C02), konsentrasi kolkisin 0\% dan lama perendaman 48 jam (C03), konsentrasi kolkisin 0\% dan lama perendaman 72 jam (C04), konsentrasi kolkisin $0.025 \%$ dan lama perendaman 1 jam (C11), konsentrasi kolkisin $0.025 \%$ dan lama perendaman 24 jam (C12), konsentrasi kolkisin $0.025 \%$ dan lama perendaman 48 jam (C13), konsentrasi kolkisin $0.025 \%$ dan lama perendaman 72 jam (C14), konsentrasi kolkisin $0.050 \%$ dan lama perendaman 1 jam (C21), konsentrasi kolkisin $0.050 \%$ dan lama perendaman 24 jam (C22), konsentrasi kolkisin $0.050 \%$ dan lama perendaman 48 jam (C23), konsentrasi kolkisin $0.075 \%$ dan lama perendaman 1 jam (C31), konsentrasi kolkisin $0.075 \%$ dan lama perendaman 24 jam (C32), konsentrasi kolkisin $0.075 \%$ dan lama perendaman 48 jam (C33), konsentrasi kolkisin $0.075 \%$ dan lama perendaman 72 jam (C34). Perlakuan penambahan dengan BA terdiri atas konsentrasi $1 \mathrm{mg} \mathrm{L}^{-1}$ (BA1) dan $2 \mathrm{mg} \mathrm{L}^{-1}$ (BA2). Terdapat 32 kombinasi perlakuan dengan masing-masing perlakuan terdiri atas 3 ulangan, sehingga terdapat 96 satuan percobaan. Setiap satuan percobaan terdiri atas 10 eksplan hasil mutasi, sehingga jumlah total eksplan adalah 960 eksplan sebagai satuan amatan. Pengolahan data hasil pengamatan dilakukan menggunakan perangkat lunak Minitab dan Microsoft Excel. Uji F dilakukan terhadap hasil pengamatan dan dilanjutkan dengan uji Tukey bila diketahui berbeda nyata pada $\alpha=0.05$.

\section{HASIL DAN PEMBAHASAN}

\section{Kondisi Umum Kultur In Vitro}

Persentase eksplan yang hidup hingga 12 MST mencapai $63.58 \%$, dengan persentase eksplan terkontaminasi dan mati masing-masing sebesar $14.69 \%$ dan $21.74 \%$. Kontaminan yang sering ditemukan selama pelaksanaan penelitian antara lain cendawan, yang dicirikan dengan hifa halus yang menutupi permukaan media kultur dan eksplan. Sumber kontaminan lain ialah bakteri, yang dicirikan dengan adanya koloni pada permukaan media kultur. Terdapat dua kemungkinan penyebab terjadinya kontaminasi, yaitu disebabkan oleh adanya kontaminan yang masuk ke dalam botol kultur ketika proses subkultur atau disebabkan oleh kontaminan yang berasal dari dalam jaringan eksplan (Cardoza 2008). Kematian eksplan pada penelitian ini diduga diakibatkan senyawa fenolik yang dihasilkan oleh eksplan, yang ditandai dengan perubahan warna media proliferasi dari putih menjadi kecoklatan. Dikeluarkannya senyawa fenolik dapat dipicu oleh berbagai macam cekaman (stress) pada eksplan, misalnya luka pada jaringan (Saltveit 2000) yang dihasilkan saat subkultur atau suhu lingkungan (Bhardwaj et al. 
2014). Kematian juga dapat terjadi akibat aplikasi kolkisin. Aplikasi kolkisin dengan konsentrasi yang terlalu tinggi pada tanaman dapat menyebabkan kerusakan pada sel, sehingga tanaman mati (Yulianti et al. 2014)

\section{Pengaruh Perlakuan Kolkisin dan BA terhadap Pertumbuhan Plb Dendrobium lasianthera}

Hasil pengamatan menunjukkan bahwa perlakuan kolkisin dan BA mempengaruhi pertumbuhan eksplan berupa jumlah plb sekunder, tunas, daun maupun akar baru yang terbentuk. Perbedaan respon pertumbuhan berdasarkan konsentrasi kolkisin dan lama perendaman terlihat secara nyata pada seluruh kelompok perlakuan (Gambar 1). Hal ini serupa dengan penelitian sebelumnya oleh Nugroho (2015) terhadap D.lasianthera, dan oleh Sarathum et al (2010) pada tanaman $D$. scabrilingue. Kondisi kultur, jenis eksplan dan genotipe merupakan tiga faktor yang dapat mempengaruhi respon terhadap zat pengatur tumbuh (Gaspar et al. 1996).
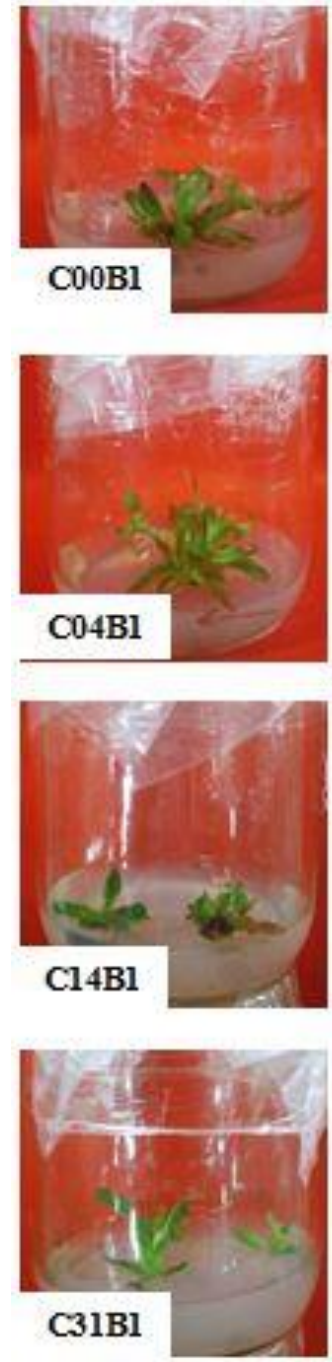
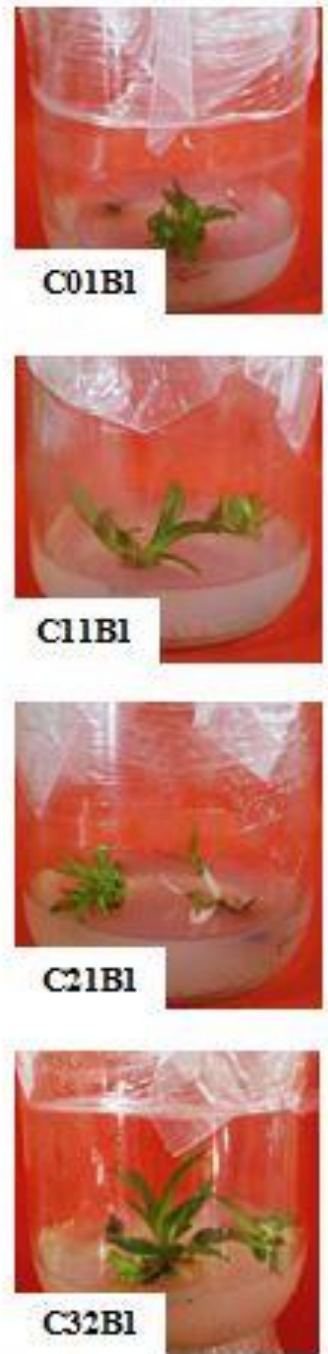
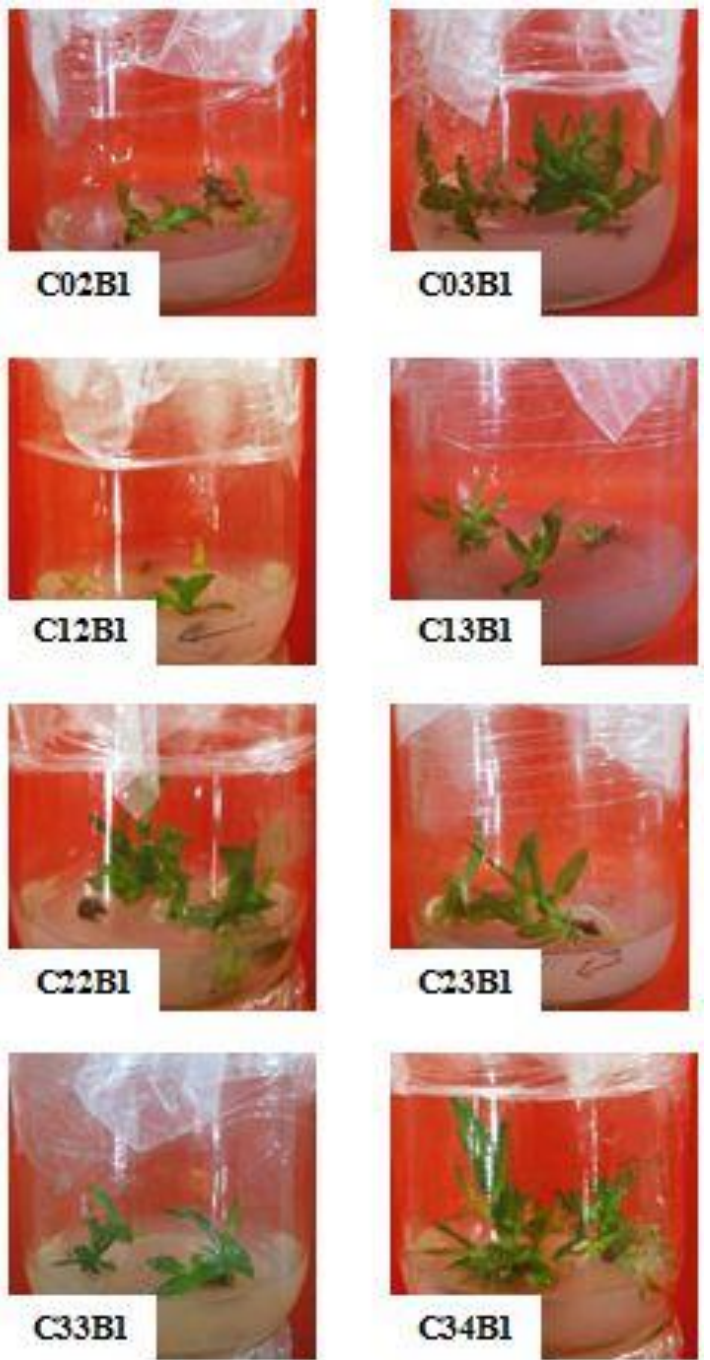

Gambar 1. Kondisi eksplan D. lasianthera pada 12 MST berdasarkan kombinasi perlakuan perendaman dengan kolkisin pada konsentrasi BA $1 \mathrm{mg} \mathrm{L}^{-1}$. 

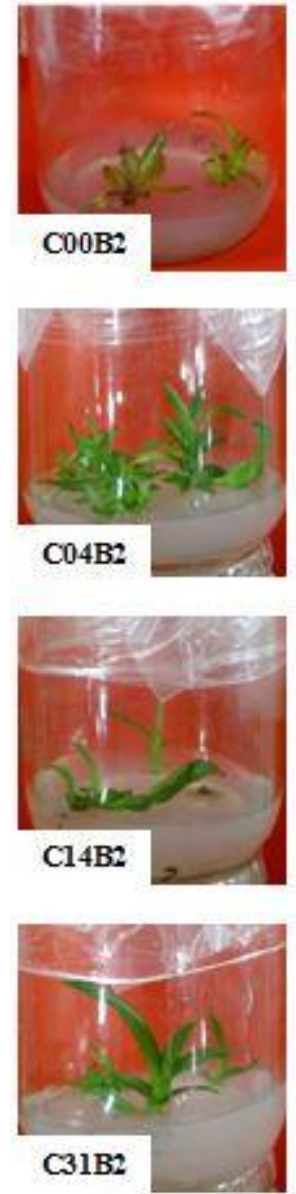
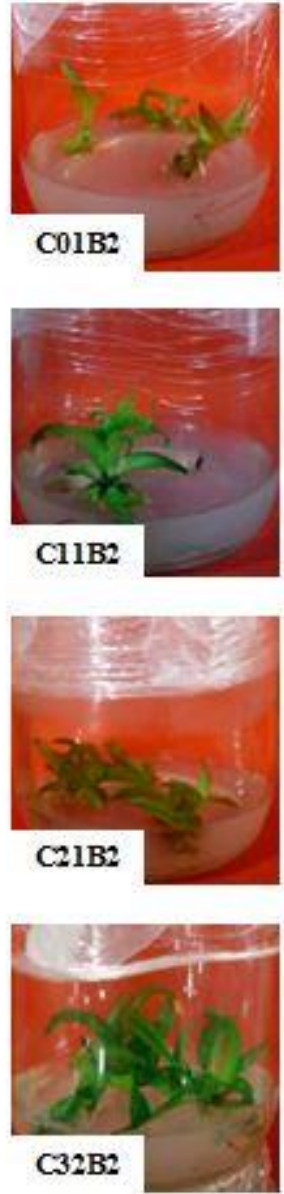
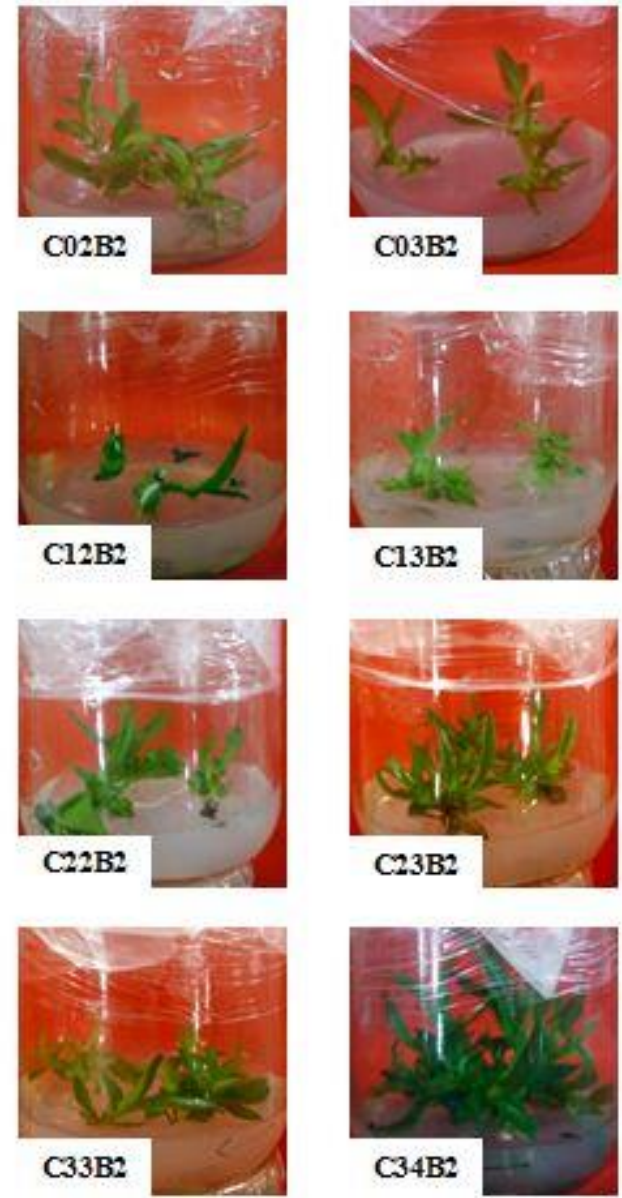

Gambar 2. Kondisi eksplan D. lasianthera pada 12 MST berdasarkan kombinasi perlakuan perendaman dengan kolkisin pada konsentrasi BA $2 \mathrm{mg} \mathrm{L}^{-1}$.

\section{Jumlah Plb Sekunder}

$P l b$ sekunder secara umum mulai terbentuk pada 2 MST. Perlakuan kolkisin berpengaruh nyata terhadap jumlah $\mathrm{plb}$ sekunder mulai 3 MST, dan berpengaruh sangat nyata pada 4 hingga 6 MST dan 11 hingga 12 MST (Tabel 1). Perlakuan konsentrasi kolkisin $0.050 \%$ dan lama perendaman 24 jam menghasilkan jumlah plb sekunder tertinggi, sementara perlakuan konsentrasi kolkisin $0.025 \%$ dan lama perendaman 24 jam menghasilkan jumlah plb sekunder terendah pada 12 MST. Namun seluruh perlakuan kolkisin tidak menghasilkan respon yang berbeda nyata dibandingkan dengan kontrol berdasarkan uji t-Dunnet.

Hasil yang diperoleh pada perlakuan kolkisin maupun BA diduga terkait dengan nilai keragaman yang tinggi, yang disebabkan oleh perlakuan kolkisin. Pada penelitian sebelumnya oleh Nugroho (2015), telah diketahui melalui uji sitologi bahwa eksplan-eksplan yang telah diberi perlakuan kolkisin bersifat kimera, yang ditunjukkan oleh adanya variasi jumlah kromosom pada sel individu. Adanya perbedaan dalam jumlah maupun susunan kromosom pada sel dapat menyebabkan terjadinya respon yang bervariasi di antara individu.

Pembentukan plb selanjutnya diikuti dengan perkembangan $p l b$ menjadi tunas. Rentang waktu yang dibutuhkan $p l b$ hingga berkembang menjadi tunas berkisar antara 1-2 minggu. Tidak terdapat interaksi yang nyata antara perlakuan kolkisin dengan BA selama periode pengamatan. 
Tabel 1. Pengaruh kombinasi perlakuan kolkisin dan BA terhadap rata-rata pertambahan jumlah $p l b$ sekunder dan jumlah Plb total Dendrobium lasianthera sampai 12 MST

\begin{tabular}{|c|c|c|c|c|c|c|c|}
\hline \multirow{3}{*}{$\begin{array}{c}\text { Konsentrasi } \\
\text { Kolkisin } \\
(\% \mathrm{w} / \mathrm{v})\end{array}$} & \multirow{3}{*}{$\begin{array}{c}\text { Lama } \\
\text { Perendaman } \\
\text { (jam) }\end{array}$} & \multicolumn{6}{|c|}{ Rataan pertambahan jumlah $p l b$ sekunder minggu ke - (MST) } \\
\hline & & 0 & 3 & 5 & 7 & 9 & 12 \\
\hline & & \multicolumn{6}{|c|}{$P l b$ sekunder/clump } \\
\hline \multicolumn{8}{|l|}{ Kolkisin (A) } \\
\hline 0.000 & 0 & 0.00 & $0.52 \mathrm{ab}$ & $1.10 \mathrm{ab}$ & 1.94 & 3.51 & $4.43 \mathrm{ab} \pm 4.21$ \\
\hline 0.000 & 1 & 0.00 & $0.52 \mathrm{ab}$ & $1.00 \mathrm{ab}$ & 1.76 & 2.74 & $3.55 \mathrm{ab} \pm 2.35$ \\
\hline 0.000 & 24 & 0.00 & $0.42 \mathrm{ab}$ & $0.91 \mathrm{ab}$ & 1.84 & 2.67 & $3.08 \mathrm{ab} \pm 2.52$ \\
\hline 0.000 & 48 & 0.00 & $0.77 \mathrm{ab}$ & $1.32 \mathrm{ab}$ & 1.94 & 2.90 & $3.37 \mathrm{ab} \pm 2.38$ \\
\hline 0.000 & 72 & 0.00 & $0.93 \mathrm{a}$ & $1.65 \mathrm{a}$ & 2.43 & 3.37 & $4.00 \mathrm{ab} \pm 2.63$ \\
\hline 0.025 & 1 & 0.00 & $0.53 \mathrm{ab}$ & $1.28 \mathrm{ab}$ & 2.32 & 3.50 & $4.43 \mathrm{a} \pm 2.78$ \\
\hline 0.025 & 24 & 0.00 & $0.28 b$ & $0.68 b$ & 1.15 & 1.91 & $1.97 b \pm 2.76$ \\
\hline 0.025 & 48 & 0.00 & $0.52 \mathrm{ab}$ & $0.88 \mathrm{ab}$ & 2.36 & 3.36 & $3.57 \mathrm{ab} \pm 3.40$ \\
\hline 0.025 & 72 & 0.00 & $0.48 \mathrm{ab}$ & $0.78 \mathrm{ab}$ & 1.28 & 2.27 & $2.94 \mathrm{ab} \pm 3.10$ \\
\hline 0.050 & 1 & 0.00 & $0.56 \mathrm{ab}$ & $1.40 \mathrm{ab}$ & 2.20 & 3.02 & $4.21 \mathrm{ab} \pm 4.05$ \\
\hline 0.050 & 24 & 0.00 & $0.58 \mathrm{ab}$ & $1.35 \mathrm{ab}$ & 2.22 & 3.76 & $5.39 \mathrm{a} \pm 4.29$ \\
\hline 0.050 & 48 & 0.00 & $0.59 \mathrm{ab}$ & $1.42 \mathrm{ab}$ & 2.41 & 2.92 & $3.53 \mathrm{ab} \pm 2.91$ \\
\hline 0.075 & 1 & 0.00 & $0.52 \mathrm{ab}$ & $0.70 \mathrm{~b}$ & 1.65 & 2.78 & $3.74 \mathrm{ab} \pm 4.16$ \\
\hline 0.075 & 24 & 0.00 & $0.30 \mathrm{~b}$ & $0.82 \mathrm{ab}$ & 2.08 & 2.54 & $3.16 \mathrm{ab} \pm 3.34$ \\
\hline 0.075 & 48 & 0.00 & $0.41 \mathrm{ab}$ & $1.02 \mathrm{ab}$ & 2.26 & 3.15 & $3.63 \mathrm{ab} \pm 3.09$ \\
\hline 0.075 & 72 & 0.00 & $0.61 \mathrm{ab}$ & $1.32 \mathrm{ab}$ & 2.75 & 3.58 & $5.09 \mathrm{a} \pm 4.76$ \\
\hline Uji F & & - & $*$ & $*$ & $*$ & tn & $* *$ \\
\hline \multicolumn{8}{|c|}{ Konsentrasi BA $\left(\mathrm{mg} \mathrm{L}^{-1}\right)$} \\
\hline \multicolumn{8}{|c|}{$\mathrm{BA}(\mathrm{B})$} \\
\hline 1 & & 0.00 & 0.50 & 1.05 & 1.92 & 2.90 & $3.71 \pm 3.51$ \\
\hline 2 & & 0.00 & 0.57 & 1.14 & 2.16 & 3.16 & $3.93 \pm 3.39$ \\
\hline Uji F & & - & tn & $\operatorname{tn}$ & tn & tn & tn \\
\hline \multicolumn{8}{|l|}{$\begin{array}{l}\text { Interaksi } \\
A \times B\end{array}$} \\
\hline Uji F & & - & tn & tn & tn & $\operatorname{tn}$ & $\operatorname{tn}$ \\
\hline $\mathrm{KK}(\%)$ & & - & 175.60 & 142.04 & 105.55 & 87.68 & 90.41 \\
\hline
\end{tabular}

Keterangan : tn: tidak berpengaruh nyata, *: berpengaruh nyata pada taraf $5 \%$, ** berpengaruh sangat nyata pada taraf $1 \%$, angkaangka yang diikuti dengan huruf yang sama pada kolom perlakuan yang sama tidak berbeda nyata pada uji Tukey taraf $5 \%$, berbeda nyata lebih besar dibanding kontrol pada uji t-Dunnet taraf $5 \%$

Seluruh kombinasi perlakuan kolkisin dan BA tidak menghasilkan plb yang berkalus selama pengamatan. Hal ini menunjukkan bahwa pembentukan plb pada eksplan anggrek $D$. lasianthera yang dikulturkan terjadi melalui direct organogenesis, yaitu proses pembentukan organ yang tidak didahului dengan pembentukan kalus. Pembentukan plb sekunder yang tidak didahului dengan pembentukan kalus lebih dikehendaki didalam perbanyakan tanaman transgenik karena waktu yang dibutuhkan untuk menghasilkan tunas baru lebih singkat (Cardoza 2008).

\section{Jumlah Tunas}

Tunas merupakan hasil diferensiasi plb sekunder yang terbentuk selama periode pengamatan. Nilai pada 0 MST pada Tabel 2 merupakan rataan jumlah tunas yang dimiliki oleh eksplan pada waktu awal penanaman, sementara nilai pada minggu setelahnya merupakan pertambahan jumlah tunas. Hasil pengamatan menunjukkan bahwa perlakuan kolkisin memberikan pengaruh yang sangat nyata terhadap jumlah tunas baru pada 6 MST serta 10 - 12 MST (Tabel 2).

Data hasil pengamatan menunjukkan bahwa perlakuan konsentrasi kolkisin $0.050 \%$ dan lama perendaman 24 jam, serta konsentrasi kolkisin $0.025 \%$ dan lama perendaman 24 jam berturut-turut merupakan perlakuan yang menghasilkan jumlah tunas tertinggi dan terendah, sejalan respon pembentukan plb sekunder. Akan tetapi, perbedaan respon antarperlakuan tidak bersifat nyata dibanding kontrol, yang ditunjukkan oleh notasi huruf yang sama (Tabel 3). Hasil uji t-Dunnet juga menunjukkan bahwa tidak terdapat perlakuan kolkisin yang berbeda nyata dengan kontrol.

Penambahan BA sampai $2 \mathrm{mgL}^{-1}$ menghasilkan jumlah tunas yang lebih tinggi dibanding $1 \mathrm{mgL}^{-1}$, dan perbedaan tersebut terlihat sangat nyata pada 4 MST dan nyata pada 
9 MST. Hal ini menunjukkan bahwa pengaruh penambahan BA terhadap diferensiasi plb menjadi tunas lebih besar daripada pengaruhnya terhadap pembentukan plb. Tidak terdapat interaksi yang nyata pada kedua faktor perlakuan sehingga dapat dikatakan pola respon terhadap konsentrasi BA pada seluruh kelompok perlakuan kolkisin bersifat serupa.

Tabel 2. Pengaruh kombinasi perlakuan kolkisin dan BA terhadap rata-rata pertambahan jumlah tunas dan jumlah total tunas Dendrobium lasianthera sampai 12 MST

\begin{tabular}{|c|c|c|c|c|c|c|c|c|c|}
\hline \multirow{3}{*}{$\begin{array}{c}\text { Konsentrasi } \\
\text { Kolkisin } \\
(\% \mathrm{w} / \mathrm{v})\end{array}$} & \multirow{3}{*}{$\begin{array}{c}\text { Lama } \\
\text { Perendaman } \\
\text { (jam) }\end{array}$} & \multicolumn{7}{|c|}{ Rataan pertambahan jumlah tunas minggu ke - (MST) } & \multirow{2}{*}{$\frac{\text { Total }}{12}$} \\
\hline & & & 0 & 3 & 5 & 7 & 9 & 12 & \\
\hline & & \multicolumn{8}{|c|}{ Tunas/clump } \\
\hline \multicolumn{10}{|l|}{ Kolkisin $(\mathrm{A})$} \\
\hline 0.000 & 0 & & 0.82 & 0.05 & 0.58 & 1.51 & 2.41 & $3.57 \mathrm{abcd} \pm 3.49$ & $4.32 \mathrm{abc} \pm 3.41$ \\
\hline 0.000 & 1 & & 0.92 & 0.67 & 0.63 & 1.35 & 2.11 & $2.85 \mathrm{abcd} \pm 2.08$ & $3.67 \mathrm{abc} \pm 2.2$ \\
\hline 0.000 & 24 & & 0.82 & 0.05 & 0.50 & 1.20 & 1.94 & $2.50 \mathrm{bcd} \pm 2.10$ & $3.44 \mathrm{abc} \pm 2.38$ \\
\hline 0.000 & 48 & & 0.88 & 0.15 & 0.91 & 1.43 & 2.34 & $2.91 \mathrm{abcd} \pm 2.11$ & $3.89 \mathrm{abc} \pm 2.14$ \\
\hline 0.000 & 72 & & 0.68 & 0.17 & 0.93 & 1.77 & 2.43 & $3.70 \mathrm{abc} \pm 2.33$ & $4.38 \mathrm{abc} \pm 2.4$ \\
\hline 0.025 & 1 & & 0.83 & 0.13 & 0.52 & 1.60 & 2.10 & $3.08 \mathrm{abcd} \pm 2.00$ & $3.85 \mathrm{abc} \pm 2.06$ \\
\hline 0.025 & 24 & & 0.85 & 0.13 & 0.40 & 0.85 & 1.34 & $1.47 \mathrm{~d} \pm 2.36$ & $2.25 c \pm 2.33$ \\
\hline 0.025 & 48 & & 0.83 & 0.21 & 0.61 & 1.64 & 2.96 & $3.43 \mathrm{abcd} \pm 3.34$ & $4.33 \mathrm{abc} \pm 2.40$ \\
\hline 0.025 & 72 & & 0.75 & 0.13 & 0.62 & 0.96 & 1.53 & $2.39 \mathrm{bcd} \pm 2.39$ & $3.23 b c \pm 2.50$ \\
\hline 0.050 & 1 & & 0.90 & 0.16 & 0.81 & 1.61 & 2.32 & $3.19 \mathrm{abcd} \pm 2.61$ & $4.19 a b c \pm 2.67$ \\
\hline 0.050 & 24 & & 0.75 & 0.17 & 0.68 & 1.53 & 2.61 & $4.85 a \pm 3.96$ & $5.61 \mathrm{a} \pm 4.07$ \\
\hline 0.050 & 48 & & 0.97 & 0.05 & 0.78 & 1.92 & 2.66 & $3.45 \mathrm{abcd} \pm 2.61$ & $4.38 \mathrm{abc} \pm 2.92$ \\
\hline 0.075 & 1 & & 0.82 & 0.12 & 0.67 & 1.16 & 1.50 & $2.29 \mathrm{~cd} \pm 2.50$ & $3.09 \mathrm{c} \pm 2.57$ \\
\hline 0.075 & 24 & & 0.88 & 0.17 & 0.71 & 1.73 & 2.14 & $2.67 \mathrm{bcd} \pm 2.32$ & $3.56 a b c \pm 2.37$ \\
\hline 0.075 & 48 & & 0.80 & 0.16 & 0.69 & 1.78 & 2.48 & $3.15 \mathrm{abcd} \pm 2.68$ & $3.95 \mathrm{abc} \pm 2.78$ \\
\hline 0.075 & 72 & & 0.92 & 0.24 & 0.74 & 1.79 & 2.80 & $4.55 \mathrm{ab} \pm 3.83$ & $5.46 \mathrm{ab} \pm 3.86$ \\
\hline Uji F & & - & & tn & th & th & tn & $* *$ & $* *$ \\
\hline \multicolumn{10}{|c|}{ Konsentrasi BA $\left(\mathrm{mg} \mathrm{L}^{-1}\right)$} \\
\hline \multicolumn{10}{|c|}{$\mathrm{BA}(\mathrm{B})$} \\
\hline 1 & & & 0.83 & 0.11 & 0.61 & 1.43 & $2.09 \mathrm{~b}$ & $3.15 \pm 2.93$ & $3.99 \pm 2.96$ \\
\hline 2 & & & 0.85 & 0.15 & 0.73 & 1.55 & $2.42 \mathrm{a}$ & $3.23 \pm 2.71$ & $4.08 \pm 2.84$ \\
\hline Uji F & & - & & $\operatorname{tn}$ & tn & tn & $*$ & $\operatorname{tn}$ & tn \\
\hline \multicolumn{10}{|l|}{$\begin{array}{l}\text { Interaksi } \\
\mathrm{A} \times \mathrm{B}\end{array}$} \\
\hline Uji F & & - & & tn & th & tn & tn & tn & tn \\
\hline $\mathrm{KK}(\%)$ & & 62.1 & & 332.6 & 151.1 & 112.6 & 90.5 & 88.5 & 70.2 \\
\hline
\end{tabular}

Respon terhadap konsentrasi BA yang tidak nyata pada sebagian besar periode pengamatan diduga disebabkan oleh adanya tingkat respon yang berbeda antara eksplaneksplan dengan perlakuan kolkisin yang berbeda. Keragaman yang dihasilkan dari induksi mutasi dapat mencakup keragaman dari segi morfologi dan fisiologi. Pengaruh hormon tanaman atau zat pengatur tumbuh melibatkan proses fisiologi berupa transfer dan respon sinyal kimiawi, sehingga perubahan fisiologis yang terjadi akibat induksi mutasi dapat mempengaruhi respon eksplan. Konsentrasi BA yang optimal untuk propagasi juga dapat bervariasi tergantung pada kelompok perlakuan bahkan individu eksplan.

\section{Jumlah Daun}

Proliferasi In Vitro ...
Perlakuan perendaman kolkisin terlihat berpengaruh nyata terhadap jumlah daun baru pada 2 MST, dan berpengaruh sangat nyata terhadap jumlah daun baru pada 12 MST (Tabel 3). Kelompok perlakuan dengan konsentrasi kolkisin $0.050 \%$ dan $0.075 \%$ cenderung menghasilkan jumlah daun yang lebih tinggi, kecuali pada perlakuan konsentrasi kolkisin $0.075 \%$ dan lama perendaman $1 \mathrm{jam}$. Perbedaan karakteristik pada seluruh kombinasi perlakuan perendaman dengan kolkisin menunjukkan bahwa waktu perendaman dan konsentrasi kolkisin mempengaruhi karakteristik tanaman yang diinduksi, sejalan dengan penelitian yang dilakukan oleh Sarathum et al. (2010) pada $D$. scabrilingue serta Yenchon dan Te-chato (2014) D. formosum. Konsentrasi BA pada media kultur tidak berpengaruh nyata terhadap jumlah daun 
baru yang terbentuk. Hal ini sesuai dengan pernyataan Srivastava (2002) bahwa BA merupakan ZPT yang berpengaruh terhadap induksi tunas atau bakal tunas. Interaksi yang nyata antara perlakuan kolkisin dan BA tidak nyata terhadap pembentukan daun pada tunas yang dihasilkan. Hasil uji t-Dunnet menunjukkan bahwa terdapat perlakuan kolkisin yang menghasilkan jumlah daun baru yang berbeda nyata dengan kontrol (Tabel 3). Perlakuan kolkisin dengan konsentrasi $0.075 \%$ dengan lama perendaman 24 jam, dan 48 jam berbeda nyata lebih tinggi dibandingkan dengan kontrol. Perlakuan lainnya tidak berbeda nyata jika dibandingkan dengan kontrol.

Tabel 3 Pengaruh kombinasi perlakuan kolkisin dan BA terhadap rata-rata pertambahan jumlah daun dan jumlah daun total Dendrobium lasianthera sampai 12 MST

\begin{tabular}{|c|c|c|c|c|c|c|c|c|c|}
\hline \multirow{3}{*}{$\begin{array}{c}\text { Konsentrasi } \\
\text { Kolkisin } \\
(\% \mathrm{w} / \mathrm{v})\end{array}$} & \multirow{3}{*}{$\begin{array}{l}\text { Lama } \\
\text { Perendaman } \\
\text { (jam) }\end{array}$} & \multicolumn{7}{|c|}{ Rataan pertambahan jumlah daun minggu ke - (MST) } & \multirow{2}{*}{$\begin{array}{c}\text { Total } \\
12 \\
\end{array}$} \\
\hline & & t & & 3 & 5 & 7 & 9 & 12 & \\
\hline & & \multicolumn{8}{|c|}{ Daun/tunas } \\
\hline \multicolumn{10}{|l|}{$\operatorname{Kolkisin}(\mathrm{A})$} \\
\hline 0.000 & 0 & & 3.40 & 0.34 & 0.61 & 0.97 & $1.46 \mathrm{ab}$ & $1.68 \mathrm{ab} \pm 1.16$ & $2.73 a \pm 1.47$ \\
\hline 0.000 & 1 & & 3.22 & 0.24 & 0.75 & 0.90 & $1.50 \mathrm{ab}$ & $2.15 \mathrm{ab} \pm 1.33$ & $3.33 a \pm 1.95$ \\
\hline 0.000 & 24 & & 3.16 & 0.16 & 0.57 & 0.71 & $0.91 b$ & $1.48 \mathrm{ab} \pm 1.09$ & $2.50 \mathrm{a} \pm 1.63$ \\
\hline 0.000 & 48 & & 2.41 & 0.53 & 1.09 & 1.31 & $1.43 \mathrm{ab}$ & $1.75 \mathrm{ab} \pm 1.23$ & $3.30 \mathrm{a} \pm 1.61$ \\
\hline 0.000 & 72 & & 3.18 & 0.46 & 1.08 & 1.44 & $1.91 \mathrm{a}$ & $2.24 \mathrm{ab} \pm 1.03$ & $2.99 a \pm 1.34$ \\
\hline 0.025 & 1 & & 2.49 & 0.29 & 1.02 & 1.06 & $1.75 \mathrm{ab}$ & $2.25 \mathrm{ab} \pm 1.45$ & $3.21 \mathrm{a} \pm 1.44$ \\
\hline 0.025 & 24 & & 2.53 & 0.32 & 0.69 & 0.96 & $1.42 \mathrm{ab}$ & $1.51 \mathrm{ab} \pm 1.34$ & $3.84 \mathrm{a} \pm 2.91$ \\
\hline 0.025 & 48 & & 3.17 & 0.42 & 0.61 & 0.99 & $1.36 \mathrm{ab}$ & $1.80 \mathrm{ab} \pm 1.13$ & $2.46 a \pm 1.20$ \\
\hline 0.025 & 72 & & 2.62 & 0.35 & 0.77 & 0.99 & $1.70 \mathrm{ab}$ & $1.64 a b \pm 1.13$ & $3.28 \mathrm{a} \pm 1.99$ \\
\hline 0.050 & 1 & & 2.88 & 0.61 & 1.13 & 1.38 & $1.58 \mathrm{ab}$ & $1.93 \mathrm{ab} \pm 1.05$ & $2.88 \mathrm{a} \pm 1.41$ \\
\hline 0.050 & 24 & & 3.23 & 0.24 & 0.78 & 1.24 & $1.64 \mathrm{ab}$ & $1.86 \mathrm{ab} \pm 1.05$ & $2.71 \mathrm{a} \pm 1.40$ \\
\hline 0.050 & 48 & & 2.88 & 0.59 & 0.85 & 1.19 & $1.84 \mathrm{a}$ & $2.29 \mathrm{ab} \pm 1.15$ & $3.16 a \pm 1.73$ \\
\hline 0.075 & 1 & & 2.68 & 0.37 & 0.69 & 1.02 & $1.34 \mathrm{ab}$ & $1.37 b \pm 0.99$ & $2.56 a \pm 1.64$ \\
\hline 0.075 & 24 & & 2.85 & 0.43 & 1.06 & 1.41 & $1.93 \mathrm{a}$ & $2.35 \mathrm{ab}^{+} \pm 1.37$ & $3.58 \mathrm{a} \pm 2.12$ \\
\hline 0.075 & 48 & & 2.23 & 0.48 & 1.00 & 1.31 & $1.90 \mathrm{a}$ & $2.41 \mathrm{a}^{+} \pm 1.15$ & $3.71 \mathrm{a} \pm 2.14$ \\
\hline 0.075 & 72 & & 3.42 & 0.52 & 1.01 & 1.15 & $1.75 \mathrm{ab}$ & $2.10 \mathrm{ab} \pm 0.86$ & $2.93 a \pm 1.15$ \\
\hline Uji F & & - & & $\operatorname{tn}$ & tn & $*$ & $*$ & $*$ & $*$ \\
\hline \multicolumn{10}{|c|}{ Konsentrasi BA $\left(\mathrm{mg} \mathrm{L}^{-1}\right)$} \\
\hline \multicolumn{10}{|c|}{$\mathrm{BA}(\mathrm{B})$} \\
\hline 1 & & 2.89 & & 0.38 & 0.81 & 1.11 & 1.66 & $2.03 \pm 1.23$ & $3.18 \pm 1.74$ \\
\hline 2 & & 2.9 & & 0.38 & 0.88 & 1.16 & 1.55 & $1.87 \pm 1.17$ & $2.98 \pm 1.77$ \\
\hline Uji F & & - & & $\operatorname{tn}$ & tn & $\operatorname{tn}$ & $\operatorname{tn}$ & $\operatorname{tn}$ & $\operatorname{tn}$ \\
\hline \multicolumn{10}{|l|}{$\begin{array}{l}\text { Interaksi } \\
\mathrm{A} \times \mathrm{B}\end{array}$} \\
\hline Uji F & & - & & $\operatorname{tn}$ & $\operatorname{tn}$ & $\operatorname{tn}$ & tn & $\operatorname{tn}$ & tn \\
\hline $\mathrm{KK}(\%)$ & & 78.77 & & 186.7 & 124.8 & 97.11 & 73.93 & 61.47 & 45.00 \\
\hline
\end{tabular}

Keterangan : tn: tidak berpengaruh nyata, *: berpengaruh nyata pada taraf $5 \%, * *$ berpengaruh sangat nyata pada taraf $1 \%$, angkaangka yang diikuti dengan huruf yang sama pada kolom yang sama tidak berbeda nyata pada uji Tukey taraf $5 \%,{ }^{+}$: berbeda nyata lebih besar dibanding kontrol pada uji t-Dunnet taraf 5\%

\section{Jumlah Akar}

Hasil pengamatan (Tabel 4) menunjukkan bahwa perlakuan kolkisin berpengaruh sangat nyata pada 9 MST dan nyata pada 12 MST. Kelompok perlakuan konsentrasi kolkisin $0 \%$ dan lama perendaman 48 jam menghasilkan jumlah akar terbanyak, sementara konsentrasi kolkisin
$0.025 \%$ dan lama perendaman 1 jam menghasilkan jumlah akar terendah. Uji t-Dunnet menunjukkan bahwa perbedaan jumlah akar yang terbentuk pada seluruh perlakuan kolkisin tidak berbeda secara nyata jika dibandingkan dengan kontrol. 
Bul. Agrohorti 5 (2) : 146-156 (2017)

Tabel 4. Pengaruh kombinasi perlakuan kolkisin dan BA terhadap rata-rata pertambahan jumlah akar dan jumlah akar total Dendrobium lasianthera sampai 12 MST

\begin{tabular}{|c|c|c|c|c|c|c|c|c|c|}
\hline \multirow{3}{*}{$\begin{array}{c}\text { Konsentrasi } \\
\text { Kolkisin } \\
(\% \mathrm{w} / \mathrm{v})\end{array}$} & \multirow{3}{*}{$\begin{array}{c}\text { Lama } \\
\text { Perendaman } \\
\text { (jam) }\end{array}$} & \multicolumn{7}{|c|}{ Rataan pertambahan jumlah akar minggu ke - (MST) } & \multirow{2}{*}{$\begin{array}{c}\text { Total } \\
12\end{array}$} \\
\hline & & 0 & & 3 & 5 & 7 & 9 & 12 & \\
\hline & & \multicolumn{8}{|c|}{ Akar/tunas } \\
\hline \multicolumn{10}{|l|}{ Kolkisin (A) } \\
\hline 0.000 & 0 & & 1.18 & 0.14 & 0.21 & $0.21 \mathrm{ab}$ & $0.24 \mathrm{ab}$ & $0.19 \pm 0.37$ & $0.64 \mathrm{ab} \pm 0.99$ \\
\hline 0.000 & 1 & & 0.88 & 0.13 & 0.15 & $0.22 \mathrm{ab}$ & $0.26 \mathrm{ab}$ & $0.28 \pm 0.67$ & $0.71 \mathrm{ab} \pm 1.31$ \\
\hline 0.000 & 24 & & 0.97 & 0.09 & 0.09 & $0.06 \mathrm{~b}$ & $0.07 \mathrm{~b}$ & $0.09 \pm 0.17$ & $0.55 a b \pm 1.18$ \\
\hline 0.000 & 48 & & 0.74 & 0.20 & 0.28 & $0.39 \mathrm{a}$ & $0.31 \mathrm{a}$ & $0.27 \pm 0.43$ & $0.58 \mathrm{ab} \pm 0.79$ \\
\hline 0.000 & 72 & & 1.12 & 0.22 & 0.26 & $0.27 \mathrm{ab}$ & $0.24 \mathrm{ab}$ & $0.22 \pm 0.37$ & $0.49 \mathrm{ab} \pm 0.92$ \\
\hline 0.025 & 1 & & 0.58 & 0.13 & 0.09 & $0.11 \mathrm{ab}$ & $0.09 \mathrm{ab}$ & $0.10 \pm 0.21$ & $0.34 \mathrm{ab} \pm 0.42$ \\
\hline 0.025 & 24 & & 0.56 & 0.12 & 0.21 & $0.24 \mathrm{ab}$ & $0.39 \mathrm{ab}$ & $0.39 \pm 0.68$ & $0.82 \mathrm{ab} \pm 0.91$ \\
\hline 0.025 & 48 & & 0.84 & 0.13 & 0.13 & $0.07 \mathrm{ab}$ & $0.06 \mathrm{ab}$ & $0.06 \pm 0.19$ & $0.35 \mathrm{ab} \pm 0.63$ \\
\hline 0.025 & 72 & & 0.92 & 0.29 & 0.24 & $0.20 \mathrm{ab}$ & $0.27 \mathrm{ab}$ & $0.20 \pm 0.34$ & $0.59 \mathrm{ab} \pm 0.80$ \\
\hline 0.050 & 1 & & 0.40 & 0.11 & 0.09 & $0.11 \mathrm{ab}$ & $0.11 \mathrm{ab}$ & $0.12 \pm 0.25$ & $0.43 \mathrm{ab} \pm 0.60$ \\
\hline 0.050 & 24 & & 0.93 & 0.04 & 0.18 & $0.24 \mathrm{ab}$ & $0.20 \mathrm{ab}$ & $0.26 \pm 0.95$ & $0.43 a b \pm 0.99$ \\
\hline 0.050 & 48 & & 0.91 & 0.26 & 0.24 & $0.22 \mathrm{ab}$ & $0.18 \mathrm{ab}$ & $0.15 \pm 0.26$ & $0.47 \mathrm{ab} \pm 0.82$ \\
\hline 0.075 & 1 & & 0.53 & 0.22 & 0.21 & $0.22 \mathrm{ab}$ & $0.15 \mathrm{ab}$ & $0.22 \pm 0.42$ & $0.60 \mathrm{ab} \pm 0.82$ \\
\hline 0.075 & 24 & & 0.47 & 0.11 & 0.12 & $0.13 \mathrm{ab}$ & $0.16 \mathrm{ab}$ & $0.26 \pm 0.40$ & $0.46 a b \pm 0.62$ \\
\hline 0.075 & 48 & & 0.86 & 0.15 & 0.09 & $0.07 \mathrm{~b}$ & $0.08 b$ & $0.07 \pm 0.19$ & $1.08 \mathrm{a} \pm 2.06$ \\
\hline 0.075 & 72 & & 1.42 & 0.12 & 0.15 & $0.10 \mathrm{ab}$ & $0.11 \mathrm{ab}$ & $0.13 \pm 0.38$ & $0.29 b \pm 0.54$ \\
\hline Uji F & & & & $\operatorname{tn}$ & $\operatorname{tn}$ & $*$ & $*$ & tn & $*$ \\
\hline \multicolumn{10}{|c|}{ Konsentrasi BA (mg L $\left.{ }^{-1}\right)$} \\
\hline \multicolumn{10}{|c|}{$\mathrm{BA}(\mathrm{B})$} \\
\hline 1 & & & 0.87 & 0.14 & 0.17 & 0.19 & 0.2 & $0.22 \pm 0.52$ & $0.60 \pm 1.09$ \\
\hline 2 & & & 0.8 & 0.17 & 0.18 & 0.18 & 0.16 & $0.16 \pm 0.35$ & $0.49 \pm 0.85$ \\
\hline Uji F & & - & & tn & tn & tn & $\operatorname{tn}$ & $\operatorname{tn}$ & tn \\
\hline \multicolumn{10}{|l|}{$\begin{array}{l}\text { Interaksi } \\
\mathrm{A} \times \mathrm{B}\end{array}$} \\
\hline Uji F & & - & & $\operatorname{tn}$ & tn & $\operatorname{tn}$ & $\operatorname{tn}$ & $\operatorname{tn}$ & $\operatorname{tn}$ \\
\hline $\mathrm{KK}(\%)$ & & 175.75 & & 292.57 & 258.69 & 244.47 & 226.21 & 243.33 & 143.36 \\
\hline
\end{tabular}

Keterangan : tn: tidak berpengaruh nyata, *: berpengaruh nyata pada taraf $5 \%$, ** berpengaruh sangat nyata pada taraf $1 \%$, angkaangka yang diikuti dengan huruf yang sama pada kolom yang sama tidak berbeda nyata pada uji Tukey taraf $5 \%,{ }^{+}$: berbeda nyata lebih besar dibanding kontrol pada uji t-Dunnet taraf 5\%

\section{Eksplan yang Mengalami Perubahan Fenotipe}

Eksplan yang mengalami perubahan fenotipe ditemukan di antara eksplan yang dikulturkan. Beberapa eksplan memiliki bentuk daun yang bergelombang (Gambar 3b), berbeda dengan bentuk daun pada kontrol yang rata (Gambar 3a). Besarnya persentase eksplan yang mengalami perubahan fenotipe berupa bentuk daun yang bergelombang pada setiap kombinasi perlakuan kolkisin berkisar antara 0\% hingga 11.7\% (Tabel 5). Persentase mutan terbanyak ditemukan pada perlakuan konsentrasi kolkisin $0.075 \%$ dan lama perendaman 72 jam. Tidak ditemukan adanya planlet dengan susunan daun yang berbeda dengan kontrol.
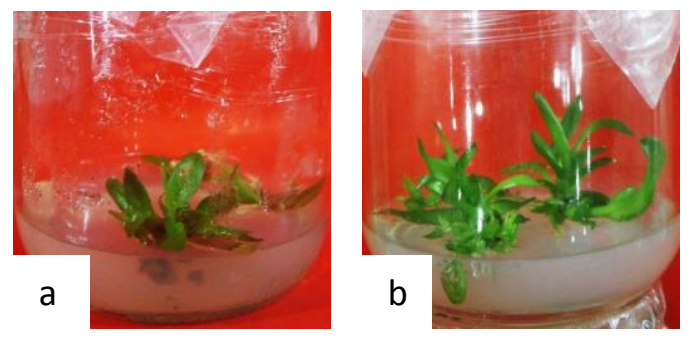

Gambar 3. Perbedaan fenotipe yang terlihat selama penelitian 
Tabel 5. Persentase eksplan yang mengalami perubahan fenotipe daun pada setiap perlakuan induksi mutasi dengan kolkisin

\begin{tabular}{cll}
\hline $\begin{array}{c}\text { Konsentrasi } \\
\text { Kolkisin } \\
(\% \mathrm{w} / \mathrm{v})\end{array}$ & $\begin{array}{l}\text { Lama Perendaman } \\
\text { (jam) }\end{array}$ & $\begin{array}{l}\text { Persentase } \\
\text { Mutan }(\%)\end{array}$ \\
\hline 0.000 & 0 & $0.0(0 / 60)$ \\
0.000 & 1 & $3.3(2 / 60)$ \\
0.000 & 24 & $3.3(2 / 60)$ \\
0.000 & 48 & $1.7(1 / 60)$ \\
0.000 & 72 & $10.0(6 / 60)$ \\
0.025 & 1 & $0.0(0 / 60)$ \\
0.025 & 24 & $6.7(4 / 60)$ \\
0.025 & 48 & $3.3(2 / 60)$ \\
0.025 & 72 & $1.7(1 / 60)$ \\
0.050 & 1 & $0.0(0 / 60)$ \\
0.050 & 24 & $8.3(5 / 60)$ \\
0.050 & 48 & $1.7(1 / 60)$ \\
0.075 & 1 & $0.0(0 / 60)$ \\
0.075 & 24 & $0.0(0 / 60)$ \\
0.075 & 48 & $1.7(1 / 60)$ \\
0.075 & 72 & $11.7(7 / 60)$ \\
\hline
\end{tabular}

\section{KESIMPULAN}

Protocorm-like bodies dan tunas anggrek Dendrobium lasianthera hasil induksi mutasi melalui perendaman dengan kolkisin menunjukkan perbedaan yang nyata dalam kemampuan membentuk plb sekunder, tunas, daun dan akar. Uji t-Dunnet menunjukkan bahwa respon yang dihasilkan pada seluruh perlakuan kolkisin hanya berbeda nyata dengan kontrol pada jumlah daun per tunas. Data menunjukkan terjadi keragaman yang tinggi akibat perlakuan kolkisin, sehingga respon eksplan terhadap perlakuan bervariasi. Peningkatan konsentrasi BA dari $1 \mathrm{mg}$ $\mathrm{L}^{-1}$ menjadi $2 \mathrm{mg} \mathrm{L}^{-1}$ dalam media proliferasi nyata meningkatkan jumlah tunas baru pada 4 dan 9 MST. Interaksi antara perlakuan kolkisin dengan zat pengatur tumbuh BA tidak nyata mempengaruhi daya proliferasi anggrek $D$. lasianthera untuk semua peubah yang ada.

Beberapa planlet hasil proliferasi menunjukkan adanya perbedaan fenotipe dari planlet kontrol. Perbedaan ditemukan pada karakter kualitatif yaitu bentuk daun. Hal ini menunjukkan bahwa perlakuan induksi mutasi kolkisin telah berhasil menginduksi perubahan fenotipe D.lasianthera.

\section{DAFTAR PUSTAKA}

[BPS] Badan Pusat Statistik. 2014. Luas Panen, Produksi dan Produktivitas Tanaman Anggrek, 2009-2013. [Internet]. [diunduh
2014 Nov 1]. Tersedia pada: http://www.bps.go.id/tab_sub/view.php? kat $=3 \&$ tabel $=1 \&$ daftar=1\&id_subyek $=55$ $\&$ notab $=42[\mathrm{BPS}]$ Badan Pusat Statistik. 2014. Tabel Ekspor Menurut Komoditi, Tahun 2013.

Bhardwaj R, Handa N, Sharma R, Kaur H, Kohli S, Kumar V, Kaur P. 2014. Lignin and Abiotic Stress: An Overview. Ahmad P dan W MR, editor. Physiological Mechanisms and Adaptation Strategies in Plants Under Changing Environments Volume 1. London (UK): Springer.

Cardoza V. 2008. Tissue Culture: The Manipulation of Plant Development. Stewart CN, editor. Plant Biotechnology. New Jersey (US): Wiley \& Sons, Inc.

Clemente M. 2009. Orchid Conservation and Trade: Are These Concepts Incompatible? Di dalam: Pridgeon AAM dan Suarez JP, editor Proceedings of The Second Scientific Conference on Andean Orchids. Universidad Tecnica Particular de Loja, Loja (EC). 46-55.

Dooghe E, Van Laere K, Eeckhaut T, Leus L, Van Huylenbroeck J. 2011. Mitotic chromosome doubling of plant tissues in vitro. Plant Cell, Tissue and Organ Culture. 104: 359-373.

Franzke CJ, Ross JG. 1957. A linear series of mutants induced by colchicine treatment. Dalam: J Heredity 48: 47-50.

Gaspar T, Kevers C, Penei C, Greppin H, Reid DM, Thorpe T. 1996. Plant Hormones and Plant Growth Regulators in Plant Tissue Culture. In Vitro Cellular \& Developmental Biology - Plant. 32: 272-289.

Harten AM. 1998. Mutation Breeding: Theory and Practical Applications. Cambridge (UK): Cambridge University Press.

Irawati. 2002. Pelestarian Jenis Anggrek Indonesia. Buku panduan Seminar Anggrek Indonesia 2002. 34-35.

Nugroho YA. 2015. Induksi Poliploid dengan Kolkisin pada Tanaman Anggrek Dendrobium lasianthera (J.J. Smith) Secara In Vitro [skripsi]. Bogor (ID): Departemen Agronomi dan Hortikultura, 
Fakultas Pertanian, Institut Pertanian Bogor.

Sakai WS. 1998. Use of a Benzyladenine Drench to Force Multiple Shoot Growth From Rhizomes of Dendrobium Jac-Hawaii 'Pearl'. Journal of Hawaiian. Pacific Agriculture. 9: 37-40.

Saltveit ME. 2000. Wound induced changes in phenolic metabolism and tissue browning are altered by heat shock. Postharvest Biology and Technology. 21: 61-59.

Sarathum S, Hegele M, Tantiviwat S, Nanakorn M. 2010. Effect of Concentration and Duration of Colchicine Treatment on Polyploidy in Dendrobium scabrilingue
L. European Journal of Horticultural Science. 75 (3): 123-127.

Srivastava LM. 2002. Plant Growth and Development. San Diego (US): Academic Press.

Yenchon S, Te-chato S. 2014. Polyploidy Induction of Dendrobium formosum by Colchicine Treatment In Vitro. Acta Horticulturae. 1025: 81-88.

Yulianti F, Purwito A, Husni A, Dinarti Diny. 2015. Induksi Tetraploid Tunas Pucuk Jeruk Siam Simadu (Citrus nobilis Lour) Menggunakan Kolkisin secara In Vitro. Jurnal Agronomi Indonesia. 43 (1) : 6671. 